\title{
Increased expression of mRNA encoding RANTES and MCP-3 in the bronchial mucosa in atopic asthma
}

\author{
N. Powell*, M. Humbert*, S.R. Durham*, B. Assoufi*, A.B. Kay*, C.J. Corrigan**
}

Increased expression of mRNA encoding RANTES and MCP-3 in the bronchial mucosa in atopic asthma. N. Powell, M. Humbert, S.R. Durham, B. Assoufi, A.B. Kay, C.J. Corrigan. CERS Journals Ltd 1996.

ABSTRACT: The selective recruitment of eosinophils into the mucosal lining of the airways is a prominent feature of atopic asthma, and is believed to be an important component in the disease pathogenesis. The precise stimuli responsible for the influx of eosinophils remain unclear. Using a semiquantitative reverse transcriptase polymerase chain reaction (RT-PCR) technique, the numbers of copies (relative to the "housekeeping" gene $\beta$-actin) of messenger ribonucleic acid (mRNA) encoding the eosinophil-active chemotactic cytokines, the factor regulated upon activation in normal T-cells expressed and secreted (RANTES) and monocyte chemotactic protein-3 (MCP-3), was measured in bronchial biopsies from atopic asthmatic patients $(n=9)$, and compared with atopic nonasthmatic $(n=8)$ and nonatopic nonasthmatic $(n=8)$ control subjects. In addition, further biopsies from each subject were prepared for immunohistochemistry and the numbers of activated (EG2+) eosinophils measured.

The expression of RANTES mRNA was significantly elevated in the atopic asthmatic group as compared to the atopic nonasthmatic controls $(p=0.013)$ and the nonatopic nonasthmatic controls $(p=0.007)$. Similarly, the expression of $\mathrm{mRNA}$ encoding MCP-3 was significantly elevated in the atopic asthmatic group, relative to the atopic nonasthmatic controls $(\mathrm{p}=\mathbf{0 . 0 1 4})$ and the nonatopic nonasthmatic control group ( $p=0.011)$. Elevated RANTES and MCP-3 mRNA expression was associated with significantly increased numbers of bronchial mucosal eosinophils in the atopic asthmatic patients as compared to the atopic nonasthmatic $(p=0.03)$ and nonatopic nonasthmatic $(p=0.006)$ control subjects.

In conclusion, we have identified elevated expression of messenger ribonucleic acid encoding RANTES and monocyte chemotactic protein-3 in the bronchial mucosa of atopic asthmatic patients relative to controls. These findings are compatible with the hypothesis that eosinophil-active $\beta$-chemokines play a role in the mechanism of eosinophil recruitment to the asthmatic bronchial mucosa.

Eur Respir J., 1996, 9, 2454-2460.
*Allergy and Clinical Immunology, National Heart \& Lung Institute at Imperial College of Science, Technology \& Medicine, London, UK. **Dept of Medicine, Charing Cross Hospital, Fulham Palace Road, London, UK

Correspondence: C.J. Corrigan

Dept of Medicine

Charing Cross Hospital

Fulham Palace Road

London W6 8RF

UK

Keywords: Asthma

atopy

chemokines

eosinophils

Received: April 41996

Accepted after revision August 161996

Supported by grants from the Medical Research Council (UK). CJC is the holder of a MRC Clinician Scientist Fellowship. $\mathrm{MH}$ was also supported by grants from the Wellcome Trust, the Institut Electricité Santé and the Société de Pneumologie de Langue Française.
The accumulation of eosinophils in the airways mucosal lining is a consistently recognized feature of asthma [1-3]. Furthermore, the numbers of infiltrating eosinophils are often observed to correlate with markers of disease severity $[2,3]$. Eosinophils are believed to mediate bronchial mucosal damage through the release of toxic proteins, enzymes and lipid mediators [3], ultimately resulting in the clinical features of asthma (variable airways obstruction and bronchial hyperreactivity).

In view of this, much attention has been focused on identifying the precise stimuli leading to the recruitment and activation of eosinophils in the bronchial mucosa. Eosinophil-active cytokines (interleukin-3 (IL-3), interleukin-5 (IL-5) and granulocyte/macrophage colony-stimulating factor (GM-CSF)) liberated locally by activated, type 2 T-helper (Th2) T-lymphocytes [4] may play a role by promoting (selectively in the case of IL-5) eosinophil differentiation from committed precursors, and enhancing survival, activation and hyperadherence of mature cells [5-8]. It is not clear, however, how far these cytokines play a role in inducing the selective migration of eosinophils from the peripheral vasculature. Furthermore, these cytokines are only weakly chemotactic for eosinophils in vitro.

Increased understanding of the properties of the $\mathrm{C}-\mathrm{C}$ (or $\beta$ ) subfamily of chemotactic cytokines, or "chemokines" has led to suggestions that certain of these mediators may play an important role in inducing selective eosinophil recruitment to the relevant mucosal surface in allergic inflammatory diseases, such as atopic asthma. In particular, the activities of the $\beta$-chemokines, the factor regulated upon activation in normal T-cells, expressed and secreted (RANTES) and monocyte chemotactic protein-3 (MCP-3), on granulocytes are restricted to eosinophils and basophils, with no demonstrable activity on neutrophils. Both RANTES and MCP-3 are selectively chemotactic for eosinophils in vitro [9-12], and exert other selective stimulatory activities on these cells, 
including rapid intracellular calcium mobilization, granule protein release and elevated expression of adhesion molecules [9-12]. More significantly, RANTES causes local accumulation of eosinophils after intradermal injection into the skin of animals [13, 14] and humans [15], indicating that certain $\beta$-chemokines may be capable of inducing selective eosinophil extravasation in vivo as well as chemotaxis in vitro. Similarly, intrabronchial challenge of mice with RANTES or MCP-3 induced an eosinophilic infiltration into the lung [16]. Thus, $\beta$ chemokines have the potential to act in concert with eosinophil-active cytokines in promoting selective eosinophil accumulation in the asthmatic bronchial mucosa.

In view of these observations, we hypothesized that the expression of messenger ribonucleic acid (mRNA) encoding the eosinophil-active chemokines, RANTES and MCP-3, is elevated in the bronchial mucosa of atopic asthmatic patients as compared with atopic and nonatopic, nonasthmatic controls. The aim of the present study was to measure the numbers of copies of mRNA encoding RANTES and MCP-3 in bronchial mucosal biopsies from patients with atopic asthma as compared to control subjects. A semiquantitative reverse transcriptase polymerase chain reaction (RT-PCR) technique was employed, in which $\beta$-chemokine mRNA copy numbers were expressed relative to those of the "housekeeping" gene, $\beta$-actin.

\section{Materials and methods}

\section{Study subjects}

The study subjects comprised atopic asthmatic patients $(n=9)$, atopic nonasthmatic control subjects $(n=8)$, and nonatopic nonasthmatic controls $(n=8)$. A comprehensive clinical assessment of each volunteer was performed to establish atopic and asthmatic status (table 1). Asthma was defined as: 1) a documented clinical history with current symptoms; 2) evidence of $>20 \%$ reversibility in forced expiratory volume in one second (FEV1) spontaneously or subsequent to inhaled $\beta_{2}$-agonists, and/or demonstration of nonspecific bronchial hyperresponsiveness in the preceding two weeks (as defined by a provocative concentration of histamine producing a $20 \%$ fall in FEV1 $\left.\left(\mathrm{PC}_{20}\right) \leq 6 \mathrm{mg} \cdot \mathrm{mL}^{-1}\right)$. In contrast, nonasthma

Table 1. - Clinical features of study subjects

\begin{tabular}{|c|c|c|c|c|c|}
\hline Clinical status & $\begin{array}{c}\mathrm{Ss} \\
\mathrm{n}\end{array}$ & $\begin{array}{l}\text { Age } \\
\text { yrs }\end{array}$ & $\begin{array}{l}\text { Sex } \\
\mathrm{M} / \mathrm{F}\end{array}$ & $\begin{array}{l}\text { FEV1 } \\
\% \text { pred }\end{array}$ & $\begin{array}{c}\mathrm{PC}_{20} \\
\mathrm{mg} \cdot \mathrm{mL}^{-1}\end{array}$ \\
\hline Atopic asthma & 9 & $\begin{array}{c}35 \\
(24-55)\end{array}$ & $8 / 1$ & $\begin{array}{c}81 \\
(55-104)\end{array}$ & $\begin{array}{c}0.16 \\
(0.02-3.66)\end{array}$ \\
\hline Atopic control & 8 & $\begin{array}{c}27 \\
(18-36)\end{array}$ & $7 / 1$ & $\begin{array}{c}98 * \\
(81-125)\end{array}$ & $>16$ \\
\hline Normal control & 8 & $\begin{array}{c}29 \\
(2-42)\end{array}$ & $4 / 4$ & $\begin{array}{c}108^{*} \\
(90-119)\end{array}$ & $>16$ \\
\hline
\end{tabular}

Each variable is expressed as a median value, where appropriate. The ranges are displayed in parenthesis. Ss: subjects; M: male; F: female; FEV1: forced expiratory volume in one second; $\mathrm{PC} 20$ : provocative concentration of histamine producing a $20 \%$ fall in $\mathrm{FEV}_{1}$; \% pred: percentage of predicted value. *: $\mathrm{p}<0.05, v s$ atopic asthma; **: $\mathrm{p}<0.005$, vs atopic asthma. was defined as: 1) a lifelong absence of asthma symptoms; 2) baseline lung function within the normal range and $<20 \%$ reversibility in FEV1 either spontaneously, or after $\beta_{2}$-agonist inhalation; 3) absence of nonspecific bronchial hyperresponsiveness (histamine PC20 >16 $\mathrm{mg} \cdot \mathrm{mL}^{-1}$ ).

Atopy was defined as a positive skin-prick test and radioallergosorbent test (RAST) of $>0.70 \mathrm{IU} \cdot \mathrm{mL}^{-1}$ (CAP system, Pharmacia Diagnostics, Sweden) to extracts of one or more aeroallergens. The atopic nonasthmatic controls suffered from perennial or seasonal rhinitis. Conversely, nonatopic subjects were demonstrated to have negative skin-prick tests and RAST $\left(<0.70 \mathrm{IU} \cdot \mathrm{mL}^{-1}\right)$ to a wide range of common aeroallergens. None of the subjects had received systemic (2 months) or topical (2 weeks) corticosteroid therapy prior to the commencement of the study, and all were apparently free from any other chronic or acute disease. Exclusion criteria included: any history of smoking, age $<18$ or $>65 \mathrm{yrs}$; and FEV $1<60 \%$ of its predicted value on the proposed day of bronchoscopy. The study was approved by the Ethics Committee of the Royal Brompton Hospital, and all subjects gave written, informed consent.

Fibreoptic bronchoscopy was performed on each patient, and two biopsies acquired from the first generation (middle or inferior lobar bronchus) or second generation (segmental bronchi) of the right bronchus, as described previously [17]. One biopsy was immediately snap frozen in liquid nitrogen and stored at $-80^{\circ} \mathrm{C}$ pending RT-PCR analysis. The second biopsy was prepared for immunohistochemistry, as described previously [17].

\section{RNA extraction and semiquantitative RT-PCR}

Total ribonucleic acid (RNA) was extracted from the biopsies by thawing with homogenization in TRI reagent (1 mL) containing $4 \mu \mathrm{L}$ Microcarrier gel (both Molecular Research Centre Inc., Oxford, UK), according to the manufacturer's instructions. The total RNA extracted from each biopsy was resuspended in $22 \mu \mathrm{L}$ of diethyl pyrocarbonate (DEPC) treated water and reverse transcribed in a total volume of $40 \mu \mathrm{L}$ using Moloney murine leukaemia virus (M-MLV) reverse transcriptase (GibcoBRL, Paisley, UK) and oligo (dT) ${ }_{12-18}$ primers (Pharmacia, Uppsala, Sweden), as described previously [18]. The resulting complementary deoxyribonucleic acid (cDNA) was stored at $-80^{\circ} \mathrm{C}$ until used.

For PCR amplification, aliquots $(5 \mu \mathrm{L})$ of cDNA (diluted 1:5) from all subjects were made up to $50 \mu \mathrm{L}$ in PCR buffer containing primers (table 2), final concentration $1.25 \mathrm{mM}$, and Taq polymerase (Gibco-BRL, total 2.5 $\mathrm{U})$, as described previously [18], except that $0.44 \mu \mathrm{g}$ of "Taqstart" antibody (Clontech, Palo Alto, USA) was added to each reaction to prevent primer extension prior to specific annealing. The cycling conditions and final $\mathrm{Mg}^{2+}$ concentration were optimized for each primer pair (table 3) to maintain efficient exponential amplification. Primer sequences for RANTES and MCP-3 were designed in accord with the published human sequences $[19,20]$, and $\beta$-actin primers specifically designed for quantitative RT-PCR were purchased from Clontech. The PCR primers employed in this study did not cross intron-exon 
Table 2. - Primer and probe nucleotide sequences

\begin{tabular}{|c|c|c|}
\hline $\begin{array}{l}\text { Target } \\
\text { cDNA }\end{array}$ & $\begin{array}{l}\text { Primer nucleotide sequences } \\
\left.\text { (5' to } 3^{\prime}\right)\end{array}$ & $\begin{array}{l}\text { Gene specific probe nucleotide sequence } \\
\left.\text { (5' to } 3^{\prime}\right)\end{array}$ \\
\hline$\beta$-actin & $\begin{array}{l}\text { FP: AAGGCCAACCGCGAGAAGATG } \\
\text { RP: ACAGGACTCCATGCCCAGGAA }\end{array}$ & GGCTGGGGTGTTGAAGGTCTCAAACATGAT \\
\hline RANTES & $\begin{array}{l}\text { FP: TTGCTCTTGTCCTAGCTTGGGAGG } \\
\text { RP: AGCAGCGCCTCAGAAGCTCTTCTA }\end{array}$ & CAAAGTGCTGGGATTACAAGGCTGAGCCAC \\
\hline MCP-3 & $\begin{array}{l}\text { FP: CAAACTGGACAAGGAGATCTGTGC } \\
\text { RP: ATGAGGTAGAGAAGGGAGGAGCAT }\end{array}$ & TCTCAGAACCACTCTGAGAAAGGACAGGGT \\
\hline
\end{tabular}

Table 3. - Thermal cycling conditions used for amplification of RANTES, MCP-3 and $\beta$-actin

\begin{tabular}{|c|c|c|c|}
\hline Primer set: & RANTES & MCP-3 & $\beta$-actin \\
\hline$\left[\mathrm{Mg}^{2+}\right] \mathrm{mM}$ & 3.0 & 5.0 & 2.5 \\
\hline Cycle number & 40 & 35 & 30 \\
\hline Denaturation temperature ${ }^{\circ} \mathrm{C}^{*}$ & 94 & 94 & 94 \\
\hline Annealing temperature ${ }^{\circ} \mathrm{C}^{*}$ & 60 & 56 & 60 \\
\hline Extension temperature ${ }^{\circ} \mathrm{C}^{*}$ & 72 & 72 & 72 \\
\hline
\end{tabular}

*: Denaturation, annealing and extension were allowed to proceed for $1 \mathrm{~min}$ with each primer set. For definitions see legend to table 2 .

boundaries; therefore, to ensure that positive signals were generated from cDNA derived from biopsy mRNA (and not contaminating genomic deoxyribonucleic acid (DNA)), two control experiments were performed. Firstly, the RNA extracted from biopsy material was treated with 1 U.reaction ${ }^{-1}$ of RQ1 ribonuclease (RNase)-free deoxyribonuclease (DNase) (Promega, Madison, USA) prior to reverse transcription and PCR amplification. Furthermore, a PCR experiment was performed (under identical conditions to those used for cDNA amplification) on $5 \mu \mathrm{L}$ of the extracted RNA to determine whether contaminating genomic DNA was apparent in these samples.

All PCR amplifications were performed in a thermal cycler (Hybaid, Teddington, UK). Serial 10 fold dilutions of control DNA ( $\beta$-actin: Clontech; RANTES and MCP-3: kind gifts from P. Nelson and G. Opdenakker, respectively), starting from a maximal number of starting copies of standard DNA of $3 \times 10^{7}$ ranging down to 0 copies, were amplified in parallel with the patient's cDNA samples. The lower limit of sensitivity of the assay was in the region of $1-3,000$ copies of starting copies of cDNA (fig. 1). For each chemokine species and $\beta$-actin, all samples along with the cDNA standards were amplified in the same PCR reaction using the same PCR mix.

Gene specific amplification was verified by visualization of the appropriate sized band on ethidium bromide stained $2.0 \%$ agarose gels following electrophoresis of PCR product. To semiquantify $\beta$-actin and $\beta$-chemokine cDNAs, $10 \mu \mathrm{L}$ of PCR amplification product from all subjects and DNA controls were denatured, Southern blotted and probed with the appropriate gene-specific internal oligonucleotide (table 2), as described previously [18], except that oligonucleotide probes were endlabelled (specific activities approximately $1 \times 10^{7}$ counts

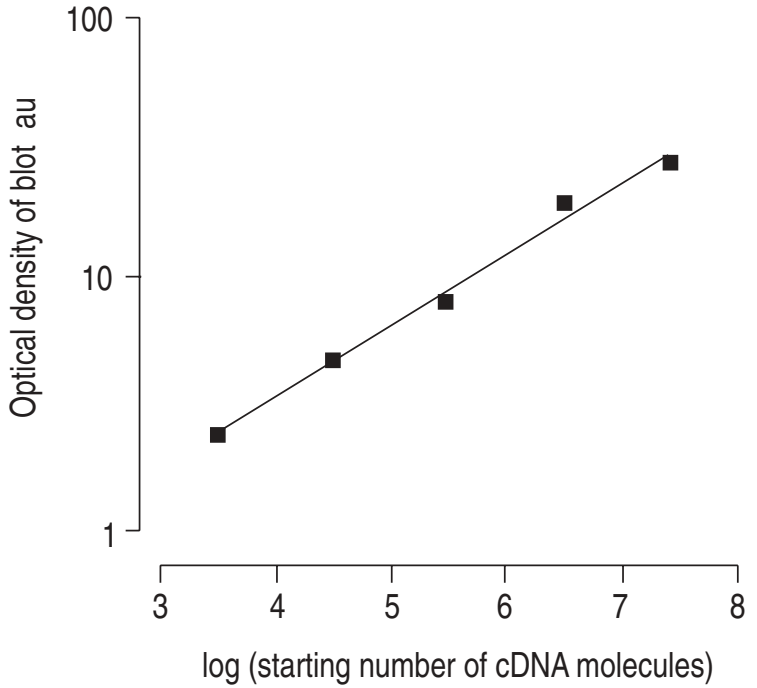

Fig. 1. - A typical standard curve graph, showing Southern blot optical densities (arbitrary units (au)) resulting from PCR amplification and probing of 10 fold serial dilutions of MCP-3 cDNA standards. The linearity of the graph demonstrates that PCR amplification was exponential. All samples from the study subjects generated blot optical densities within the linear range of the standard curve. Standard curve graphs constructed from RANTES and $\beta$-actin standards were very similar to the MCP-3 graph in terms of linearity and sensitivity. PCR: polymerase chain reaction; MCP-3 monocyte cytotactic protein3; cDNA: complementary deoxyribonucleic acid; RANTES: factor regulated upon activation in normal T-cells, expressed and secreted.

per minute $\left.(\mathrm{cpm}) \cdot \mathrm{ng}^{-1}\right)$ with $\gamma$-32P-adenosine triphosphate (ATP) (Amersham, Little Chalfont, UK) using T4 polynucleotide kinase (Promega), and then purified on Sepharose G-20 spin columns (Pharmacia). Following two high stringency washes $(1 \times$ standard sodium citrate $(\mathrm{SSC}) /$ $0.1 \%$ sodium dodecyl sulphate $(\mathrm{SDS})$ at $55^{\circ} \mathrm{C}$ ) of the membranes, autoradiography was performed using $\mathrm{X}$ OMAT AR film (Eastman Kodak, Rochester, NY). Exposed film was developed and the optical density of the blot autoradiographs measured using an automated flat bed densitometer and associated software (Quantity One Software, PDI Inc., New York, NY). Positive annealing of the gene-specific probes further verified the specificity of PCR amplification.

Quantification was performed by constructing standard curves relating the optical density of the blots produced by amplification of the 10 fold serial dilutions of DNA standards to their starting concentrations (fig. 1). In each case, the logarithms of the blot optical densities were approximately linearly related to the starting 
concentrations of the DNA standards within the range of concentrations measured. The optical density measurements from each blotted subject sample were comfortably within the linear range of the 10 fold serially diluted standards, and thus could be accurately extrapolated from the standard curve graphs. The optical densities of the blots from each amplified cDNA species from the subject samples were then expressed in terms of the numbers of starting copies of standard DNA molecules required to generate a blot of equivalent optical density. Finally, for each subject sample the numbers of starting copies of $\beta$-chemokine cDNA were expressed as percentages of the numbers of starting copies of $\beta$ actin cDNA. No signals were obtained from blotted, irrelevant DNA, or amplified water controls.

\section{Immunohistochemistry}

Sections, $6 \mu \mathrm{m}$ thick, were cut from frozen biopsies onto slides coated with $0.1 \%$ poly-L-lysine (BDH, Leicester, UK). The sections were air-dried for $2 \mathrm{~h}$ at room temperature and stored at $-80^{\circ} \mathrm{C}$ until analysed. Immunohistochemistry was performed using the alkaline phosphatase antialkaline phosphatase method, as described previously [17]. A mouse monoclonal antibody (antiEG2: Sanbio BV, Amsterdam, The Netherlands) specific for the cleaved form of eosinophil cationic protein was employed to identify eosinophils.

\section{Statistical analysis}

All data were analysed by nonparametric statistics using a software package (Minitab, State College, PA, USA). Significant intergroup variability was first established using the Kruskal-Wallis test. The Mann-Whitney U-test was then employed between groups to determine significance. A p-value of less than 0.05 was considered significant.

\section{Results}

The clinical and demographic features of the three subject groups are shown in table 1 . The histamine PC20 for the asthmatics ranged $0.02-3.66 \mathrm{mg} \cdot \mathrm{mL}^{-1}$, whereas the corresponding values in the nonasthmatic groups were uniformly $>16 \mathrm{mg} \cdot \mathrm{mL}^{-1}$. In addition, the asthmatics had significantly lower prebronchodilator FEV1 measurements, expressed as a percentage of the predicted value, as compared both with the atopic $(\mathrm{p}<0.05)$ and nonatopic $(\mathrm{p}<0.005)$ nonasthmatic controls.

Productive RNA extraction and cDNA synthesis was demonstrable, since all patient samples generated strong $\beta$-actin signals (fig. 2) by PCR and Southern dot blot analysis (the minimum number of starting cDNA molecules encoding $\beta$-actin was 28,000$)$. The absence of contaminating genomic DNA was demonstrated by PCR amplification of extracted RNA samples. No chemokine or $\beta$-actin signals were generated from any of the RNA samples in the presence of a positive control cDNA.

The numbers of copies of mRNA encoding RANTES (relative to $\beta$-actin) were significantly elevated in bronchial biopsies from the atopic asthmatics, as compared both

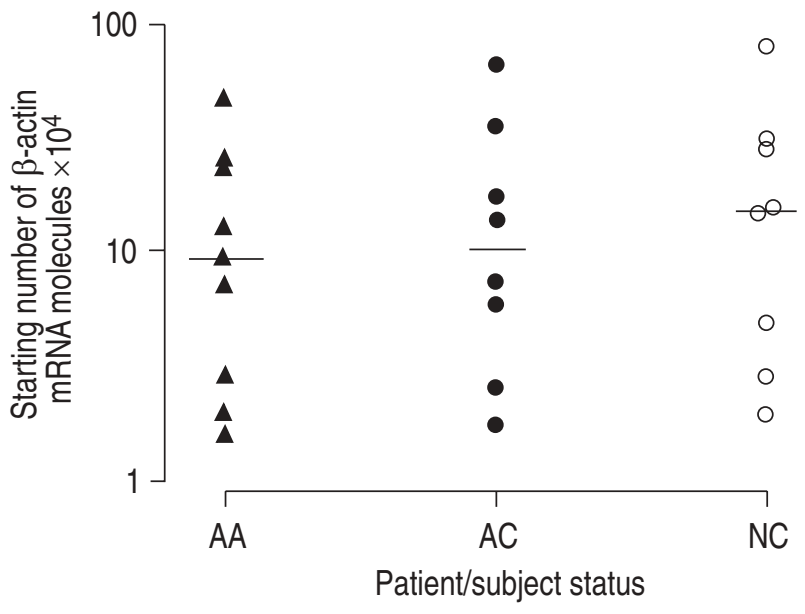

Fig. 2. - The numbers of starting copies of cDNA encoding the "housekeeping" gene, $\beta$-actin, in bronchial biopsies from atopic asthmatic (AA) patients $(n=9)$, atopic control (AC) subjects $(n=8)$, and normal control $(\mathrm{NC})(\mathrm{n}=8)$. Median values are represented by the horizontal bars. The efficiency of RNA extraction and cDNA synthesis is demonstrable, since all of the $\beta$-actin signals are strong and equivalent in each subject group. RNA: ribonucleic acid; cDNA: complimentary deoxyribonucleic acid; mRNA: messenger ribonucleic acid.

with the atopic $(\mathrm{p}=0.013)$ and nonatopic $(\mathrm{p}=0.007)$ nonasthmatic controls (fig. 3). The numbers of copies of RANTES mRNA in biopsies from the nonasthmatic controls were statistically equivalent, regardless of atopic status. Similarly, the numbers of copies of mRNA encoding MCP-3 (relative to $\beta$-actin) were significantly increased in the same biopsies from the atopic asthmatics, as compared with the atopic $(\mathrm{p}=0.014)$ and nonatopic $(\mathrm{p}=$ 0.011) nonasthmatic control subjects (fig. 4). No significant differences in MCP-3 mRNA copy numbers were detected between the atopic and nonatopic nonasthmatic controls.

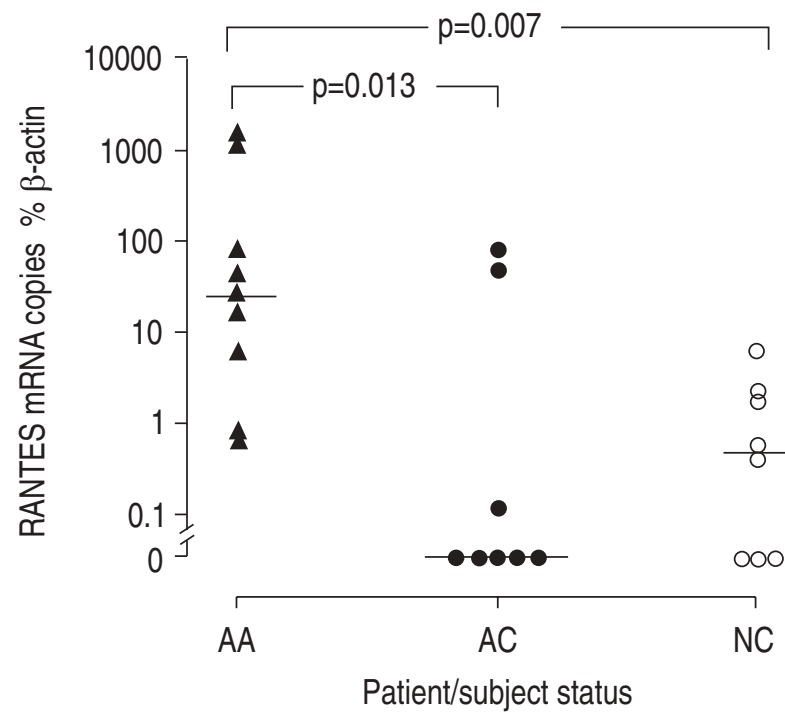

Fig. 3. - The number of copies of RANTES mRNA (expressed relative to $\beta$-actin) in bronchial biopsies from atopic asthmatic (AA) patients $(\mathbf{\Lambda})$, atopic nonasthmatic control (AC) subjects $(\bullet)$ and nonatopic nonasthmatic control (NC) subjects $(\mathrm{O})$. Bars illustrate median copy numbers. Statistical analysis by Mann-Whitney U-test. For definitions see legend to figures 1 and 2 . 




Fig. 4. - The number of copies of MCP-3 mRNA (expressed relative to $\beta$-actin) in bronchial biopsies from atopic asthmatic (AA) patients $(\boldsymbol{\Lambda})$, atopic nonasthmatic control (AC) subjects $(\bullet)$ and nonatopic nonasthmatic control (NC) subjects (O). Bars illustrate median copy numbers. Statistical analysis by Mann-Whitney U-test. For definitions see legend to figures 1 and 2 .

The numbers of EG2+ eosinophils were significantly elevated in the bronchial mucosal sections of the atopic asthmatic patients, as compared to the atopic nonasthmatic $(p=0.03)$ and nonatopic nonasthmatic $(p=0.006)$ control subjects. There was no significant difference ( $p>0.05)$ between the numbers of eosinophils in bronchial biopsies from the atopic nonasthmatic controls as compared to the nonatopic nonasthmatic controls (fig. 5). In the atopic asthmatic group, the numbers of copies of RANTES and MCP-3 mRNA (relative to $\beta$-actin) did not correlate with the number of infiltrating eosinophils.

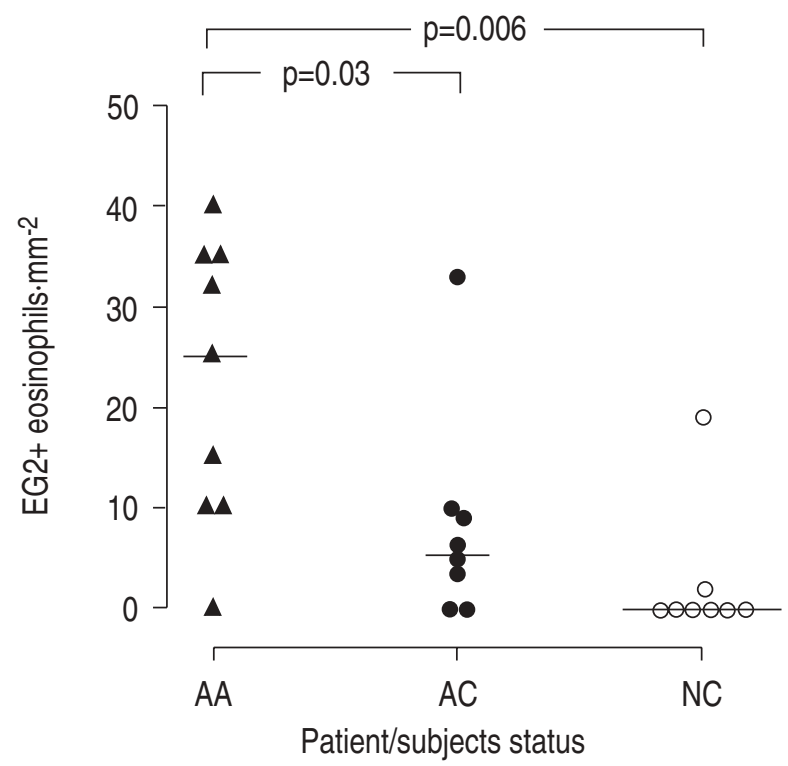

Fig. 5. - The numbers of activated eosinophils $\mathrm{mm}^{-2}$ of submucosa in bronchial biopsy sections from atopic asthmatic (AA) patients ( $\mathbf{\Delta}$ ), atopic nonasthmatic control (AC) subjects $(\bullet)$ and nonatopic nonasthmatic control (NC) subjects (O). Bars illustrate median cell numbers. Statistical analysis by Mann-Whitney U-test.

\section{Discussion}

In this study, we have demonstrated significantly elevated expression, relative to $\beta$-actin, of mRNA encoding the eosinophil-active $\beta$-chemokines, RANTES and MCP3 , in the bronchial mucosa of atopic asthmatics, as compared with atopic and nonatopic nonasthmatic control subjects. This expression was associated with increased local numbers of eosinophils. These data are consistent with the hypothesis that locally secreted eosinophilselective $\beta$-chemokines play a role in the mechanism of eosinophil recruitment to the asthmatic bronchial mucosa, and are thus potentially important mediators of disease.

It is worth noting that elevated bronchial mucosal expression of RANTES and MCP-3 mRNA was demonstrably not a feature of atopy per se, but instead a feature specific to atopic asthma. Furthermore, since the atopic nonasthmatic subjects in the present study had allergic rhinitis, with possible elevation of $\beta$-chemokine secretion locally in the nasal mucosa, our findings suggest that we have not detected elevated chemokine mRNA expression in itinerant leucocytes, activated remote from the site of the disease. It is also noteworthy that $\beta$-chemokine mRNA expression was detectable in a proportion of the control subjects. This might reflect a basal, physiological degree of chemokine expression in the bronchial mucosa, allowing the trafficking of patrolling leucocytes involved in host defence. It also highlights the sensitivity of the RT-PCR technique.

The data reported here are consistent with other recent studies showing elevated local RANTES and MCP-3 mRNA expression in association with allergen challenge of the skin [21] and nasal mucosa [22], in which eosinophil influx is a prominent feature. In addition to their eosinophil-active properties, both RANTES [23] and MCP-3 [24, 25] show chemotactic activity for Tlymphocytes (CD4+ "memory" T-cells in the case of RANTES), cells which have also been implicated in the pathogenesis of asthma. Interestingly, both of these chemokines also induce histamine release by human basophils $[12,26]$, another cellular mechanism implicated in allergic inflammation. Recent evidence indicates that certain $\beta$-chemokines, including RANTES, might be capable of enhancing immunoglobulin E (IgE) synthesis, further supporting a role for these mediators in allergic reactions [22].

The measurement of cytokine mRNA expression, using the RT-PCR technique described here, is an advantageous approach, since it permits the analysis of the mRNA profiles derived from millions of cells contained within an entire bronchial biopsy, in contrast to the much smaller numbers of cells analysed within a tissue section, as might be examined by immunohistochemical or in situ hybridization techniques. The principal reservation with this technique, and any other in which mRNA expression is examined, is that mRNA expression might not necessarily equate with synthesis of the corresponding protein. It is arguable, however, that demonstration of mRNA expression is more physiologically relevant, since it implies de novo synthesis of the relevant protein, whereas the detection of protein expression might reflect storage or even uptake of proteins secreted by other cells. However, it was recently demonstrated [27], in an 
allergen challenge model of allergic rhinitis, that elevated RANTES mRNA expression was associated with increased expression of the protein product. Thus, there is a good precedent for the assumption that increased expression of chemokine mRNA is associated with elevated expression of the corresponding protein.

The demonstration of elevated RANTES mRNA expression in lymph node granulomas of patients with sarcoidosis and tuberculosis (prototypical delayed-type hypersensitivity reactions), as compared with controls [28], suggests that localized $\beta$-chemokine expression might be a feature of inflammatory mechanisms other than those involved in allergic inflammation. In the case of asthma, it seems probable that net eosinophil accumulation in the bronchial mucosa would be influenced not only by chemokines but by cytokines (such as IL3, IL-5 and GM-CSF), which may influence eosinophil endothelial adhesion, transmigration, and subsequent survival. Tissue eosinophil numbers might reflect the rate of local eosinophil death or apoptosis, which is not known to be influenced by $\beta$-chemokines. Thus, RANTES and MCP-3 expression might be necessary, but not sufficient to effect local eosinophil accumulation. Furthermore, other $\beta$-chemokines, such as the recently described eotaxin [29], which has eosinophil-specific chemotactic and endothelial transmigatory activities, may also play a role. Given this multiplicity of potential influences on eosinophil accumulation within the asthmatic bronchial mucosa, it is perhaps not surprising that we did not observe a direct correlation with the degree of RANTES or MCP-3 mRNA expression considered in isolation. This does not, however, detract from our hypothesis that these mediators play some role in the mechanism of eosinophil recruitment to the asthmatic bronchial mucosa.

It was not the purpose of this study to examine the cellular sources of $\beta$-chemokine mRNA in asthmatic inflammation. Possible cellular sources of RANTES and MCP-3 include infiltrating leucocytes, such as T-cells [19], monocytes [30] and eosinophils [31], as well as bronchial epithelial cells $[32,33]$. An interesting future project would be to identify the cell populations responsible for the in situ production and release of $\beta$-chemokines with eosinophil chemotactic properties.

In conclusion, these data support the hypothesis that the $\beta$-chemokines, RANTES and MCP-3, represent part of the molecular apparatus responsible for the selective recruitment of eosinophils to the bronchial mucosa in atopic asthma.

Acknowledgements: The authors wish to thank P. Nelson (Dept of Pediatrics, Stanford University, Stanford, CA, USA) and G. Opdenakker (Laboratory of Molecular Medicine, Rega Institute, University of Leuven, Belgium) for their kind gifts of RANTES and MCP-3, respectively (positive control DNAs). They also wish to acknowledge the assistance of the staff of Lind ward, Royal Brompton Hospital.

\section{References}

1. Djukanovic R, Wilson JW, Britten KM, et al. Quantification of mast cells and eosinophils in the bronchial mucosa of symptomatic atopic asthmatics and healthy control subjects. Am Rev Respir Dis 1990; 142: 863-871.

2. Bousquet J, Chanez P, Lacoste JY, et al. Eosinophilic inflammation in asthma. N Engl J Med 1990; 323: 1033-1039.

3. Bradley BL, Azzawi M, Jacobson M, et al. Eosinophils, T-lymphocytes, mast cells, neutrophils and macrophages in bronchial biopsy specimens from atopic subjects with asthma: comparison with biopsy specimens from atopic subjects without asthma and normal control subjects, and relationship to bronchial hyperresponsiveness. $J$ Allergy Clin Immunol 1991; 8: 661-674.

4. Corrigan CJ, Kay AB. T-cells and eosinophils in the pathogenesis of asthma. Immunology Today 1992; 13: 501-507.

5. Clutterbuck EJ, Hirst EMA, Sanderson CJ. Human interleukin-5 (IL-5) regulates the production of eosinophils in human bone marrow cultures: comparison and interaction with IL-1, IL-3, IL-6 and GM-CSF. Blood 1989; 73: $1504-1512$.

6. Lopez AF, Williamson DJ, Gamble JR, et al. Recombinant human granulocyte/macrophage colony-stimulating factor stimulates in vitro mature human neutrophil and eosinophil function, surface receptor expression, and survival. J Clin Invest 1986; 78: 1220-1228.

7. Rothenburg ME, Owen WF, Silberstein DS, et al. Human eosinophils have prolonged survival, enhanced functional properties, and become hypodense when exposed to human interleukin-3. J Clin Invest 1988; 81: 19861992.

8. Rothenburg ME, Peterson J, Stevens RL, et al. IL-5 dependent conversion of normodense human eosinophils to the hypodense phenotype uses $3 \mathrm{~T} 3$ fibroblasts for enhanced viability, accelerated hypodensity, and sustained antibody-dependent cytotoxicity. J Immunol 1989; 143: 2311-2316.

9. Kameyoshi Y, Dörschner A, Mallet AI, Christophers E, Schröder J-M. Cytokine RANTES released by thrombin-stimulated platelets is a potent chemoattractant for human eosinophils. J Exp Med 1992; 176: 587-592.

10. Rot A, Krieger M, Brunner T, Bischoff SC, Schall TJ, Dahinden CA. RANTES and macrophage inflammatory protein- $1 \alpha$ induces the migration and activation of normal human eosinophil granulocytes. J Exp Med 1992; 176: 1489-1495.

11. Alam R, Stafford S, Forsythe P, et al. RANTES is a chemotactic and activating factor for human eosinophils. J Immunol 1993; 150: 3442-3447.

12. Dahinden CA, Geiser T, Brunner T, et al. Monocyte chemotactic protein-3 is a most effective basophil- and eosinophil-active chemokine. J Exp Med 1994; 179: 751-756.

13. Meurer R, Van Riper G, Feeney W, et al. Formation of eosinophilic and monocytic intradermal inflammatory sites in the dog by injection of human RANTES but not human monocyte chemoattractant protein-1, macrophage inflammatory protein- $1 \alpha$, or human interleukin-8. J Exp Med 1993; 178: 1913-1921.

14. Ponath PD, Qin S, Ringler DJ, et al. Cloning of the human eosinophil chemoattractant, eotaxin. J Clin Invest 1996; 97: 604-612.

15. Beck L, Stellato C, Dalke S, et al. Cutaneous injection of RANTES causes eosinophil recruitment: comparison of nonallergic and allergic human subjects (Abstract). $J$ Allergy Clin Immunol 1996; 97: 425.

16. Malick A, Stafford S, Li H, Forsythe P, Alam R, Galveston TX. The lung inflammatory responses to $\mathrm{CC}$ chemokines, MCP-1, MCP-3, MIP-1 $\alpha$ and RANTES, in mice challenged in vivo (Abstract). J Allergy Clin Immunol 1996; 97: 404 
17. Humbert M, Grant JA, Taborda-Barata L, et al. High affinity $\operatorname{IgE}$ receptor (FceRI)-bearing cells in bronchial biopsies from atopic and nonatopic asthma. Am J Respir Crit Care Med 1996; 153: 1931-1937.

18. Doi S, Gemou-Engesaeth V, Kay AB, Corrigan CJ. Polymerase chain reaction quantification of cytokine messenger RNA expression in peripheral blood mononuclear cells of patients with acute exacerbations of asthma: effect of glucocorticoid therapy. Clin Exp Allergy 1994; 24: 854-867.

19. Schall TJ, Jongstra J, Dyer BJ, et al. A human T-cellspecific molecule is a member of a new gene family. $J$ Immunol 1988; 141: 1018-1025.

20. Minty A, Chalon P, Guillemot C. Molecular cloning of the MCP-3 chemokine gene and regulation of its expression. Eur Cytokine Netw 1993; 4: 99-110.

21. Ying S, Taborda-Barata L, Meng Q, Humbert M, Kay AB. The kinetics of allergen-induced transcription of messenger RNA for monocyte chemotactic protein-3 and RANTES in the skin of human atopic subjects: relationship to eosinophil, T-cell, and macrophage recruitment. J Exp Med 1995; 181: 2153-2159.

22. Kimata H, Yoshida A, Ishioka K, Fujimoto M, Lindley I, Furusho K. RANTES and macrophage inflammatory protein-1 $\alpha$ selectively enhance immunoglobulin (IgE) and IgG4 production by human B-cells. J Exp Med 1996; 183: 2397-2402.

23. Schall TJ, Bacon K, Toy KJ, Goeddel DV. Selective attraction of monocytes and T-lymphocytes of the memory phenotype by cytokine RANTES. Nature 1990; 347: 669-671.

24. Loetscher P, Seitz M, Clark-Lewis I, Baggiolini M, Moser B. Monocyte chemotactic proteins, MCP-1, MCP2 and MCP-3, are major attractants for human CD4+ and CD8+ T-lymphocytes. FASEB J 1994; 8: 1055-1060.
25. Taub DD, Proost P, Murphy WJ, et al. Monocyte chemotactic-protein-1 (MCP-1) -2 and -3 are chemotactic for human T-lymphocytes. J Clin Invest 1995; 95: 1370-1376.

26. Kuna P, Reddigari T, Schall TJ, Rucinski D, Viksman MY, Kaplan AP. RANTES, a monocyte and T-lymphocyte chemotactic cytokine, releases histamine from human basophils. J Immunol 1992; 149: 636-642.

27. Rajakulasingam K, Hamid Q, O'Brien F, et al. Increases in RANTES mRNA and protein in the nasal secretions in hay fever patients after allergen challenge (Abstract). J Allergy Clin Immunol 1996; 97: 193.

28. Devergne O, Marfaing-Koda A, Schall T, et al. Production of the RANTES chemokine in delayed-type hypersensitivity reactions: involvement of macrophages and endothelial cells. J Exp Med 1994; 179: 1689-1694.

29. Griffiths-Johnson DA, Collins PD, Rossi AG, Jose PJ, Williams TJ. The chemokine, eotaxin, activates guineapig eosinophils in vitro and causes their accumulation into the lung in vivo. Biochem Biophys Res Commun 1993; 197: 1167-1172.

30. Schall TJ, Lu LH, Gillett N, Amento EP. RANTES/sis cytokine gene expression in rheumatoid synovium as analysed by in situ hybridisation (Abstract). Arthritis Rheum 1991; 34: S117.

31. Ying S, Meng Q, Taborda-Barata LM, et al. Human eosinophils express messenger RNA encoding RANTES and store and release biologically active RANTES protein. Eur J Immunol 1996; 26: 70-76.

32. Stellato C, Beck LA, Gorgone GA, et al. Expression of the chemokine RANTES by a human bronchial epithelial cell line. J Immunol 1995; 155: 410-418.

33. Wang JH, Devalia JL, Xia C, Sapsford RJ, Davies RJ. Expression of RANTES by human bronchial epithelial cells in vitro and in vivo and the effect of corticosteroids. Am J Respir Cell Mol Biol 1996; 14: 27-35. 